\title{
Health concerns of women after mastectomy
}

\author{
Problemy zdrowotne kobiet po mastektomii
}

\section{Patrycja Groszek¹, Bolesław Samoliński², Edyta Krzych-Fałta²}

\author{
${ }^{1}$ Klinika Chirurgii Ogólnej i Żywienia Klinicznego, Warszawski Uniwersytet Medyczny \\ 2Zakład Profilaktyki Zagrożeń Srodowiskowych i Alergologii, Warszawski Uniwersytet Medyczny \\ CORRESPONDING AUTHOR /AUTOR DO KORESPONDENCJ: \\ Patrycja Groszek \\ Klinika Chirurgii Ogólnej i Żywienia Klinicznego \\ Warszawski Uniwersytet Medyczny \\ ul. Czerniakowska 231, 00-416 Warszawa \\ e-mail: patrycja.groszek@gmail.com
}

\section{STRESZCZENIE PROBLEMY ZDROWOTNE KOBIET PO MASTEKTOMII}

Wprowadzenie. Choroba nowotworowa i jej leczenie może być przyczyną poważnych zaburzeń psychofizycznych, które znacznie ograniczają samodzielność i niezależność chorych oraz pogarszają jakość życia. Amputacja piersi narusza obraz kobiety zarówno w jej ocenie, jak i w odbiorze społecznym. Następstwem mastektomii są problemy w sferze fizycznej, które ograniczają czynności dnia codziennego, jak i w sferze emocjonalnej - związane z obniżeniem poczucia kobiecości.

Cel pracy. Celem pracy była identyfikacja problemów zdrowotnych kobiet po mastektomii.

Materiał i metodyka. Badaniem objęto 40 losowo wybranych kobiet po mastektomii w wieku powyżej 20 lat. Narzędziem badawczym wykorzystanym w pracy była autorska ankieta, składająca się z 28 pytań. Pytania miały na celu zebranie informacji na temat problemów zdrowotnych kobiet po mastektomii. Analizę wykonano w programie Statistica.

Wyniki. Choroba zmieniła życie na gorsze u 55\% kobiet po mastektomii, u 35\% nie wywarła wpływu, zaś 10\% respondentek uznało, że choroba zmieniła ich życie na lepsze. Na częste występowanie obniżenia nastroju, przygnębienia, smutku skarżyło się 22,5\% badanych, u 52,5\% kobiet emocje te występowały czasami. Po zabiegu mastektomii 90\% ankietowanych korzystało z protezy piersi. Zmniejszenie sprawności po operacji odczuło 72,5\% kobiet, natomiast 27,5\% odnotowało brak zmian.

Słowa kluczowe: mastektomia, rak piersi, problemy zdrowotne

\section{ABSTRACT WEALTH CONCERNS OF WOMEN AFTER MASTECTOMY}

Introduction. Cancer and its treatment can cause serious mental and physical disorders that greatly limit the autonomy and independence of patients and reduce their quality of life. Mastectomy violates woman's image both in their self-assessment and in their public reception. Among the consequences after mastectomy, there are problems in the physical sphere, which reduce everyday activities, there also appear problems with the mental state associated with the reduction of the sense of feminity.

Aim. The aim of the study was to identify health concerns of women after mastectomy.

Material and methods. The study included 40 randomly selected women after mastectomy aged over 20 . The research tool used in the study was the original survey, consisting of 28 questions. The questions were designed in order to gather information about the health concerns of women after mastectomy. The analysis was performed using Statistica software.

Results. The disease changed for worse lives in $55 \%$ of women after mastectomy; $35 \%$ reported no impact and $10 \%$ of respondents admitted that the disease changed their lives for the better. The number of $22.5 \%$ of interviewees complained of frequently occurring low mood, depression and sadness, while $52.5 \%$ have experienced these emotions sometimes. Approximately $90 \%$ of respondents have been using a breast prosthesis after mastectomy. As many as $72.5 \%$ of women reported decrease in physical fitness after surgery, while $27.5 \%$ did not experience any change.

Conclusions. The mastectomy procedure has a negative impact on physical and emotional state of women.

Key words: mastectomy, breast cancer, health concerns 


\section{INTRODUCTION}

Breast cancer is one of the most common malignant neoplasms among women in Poland. About 16,000 of Polish women contract it every year, what constitutes a crucial social issue $[1,2]$. Although success rates in this case are increasing, breast cancer is still considered as severe and incurable disease [3]. Breast examination and prophylactic exams allow early detection of neoplastic lesions and implementation of appropriate treatment. Unfortunately, in many cases, after the detection of the disease, the methods such as chemotherapy, hormonotherapy or radiotherapy are not fully effective and a mastectomy becomes necessary.

Breast removal is a procedure which has a lot of side effects. It results in worsening of physical and psychological condition. It also causes social and work maladjustment, which are related to the worse perception of one's own body image [4].

\section{Problems in the psychological sphere}

For women, breasts constitute a symbol of feminity and maternity. Their amputation contributes to serious stress, a feeling of shame, prolonged low mood or depression $[4,5]$. Psychological repercussions often stem from the family, professional and aesthetic background. Family consequences are linked to the fear of death, children bereavement or the loss of a partner. In turn, work-related repercussions are linked to the possibility of losing a job and social position. Aesthetic consequences are related to low self esteem, resulting from the decline in physical attractiveness.

In the course of treatment, psychological support of the relatives plays a crucial role. The family takes care of an ill family member and participates in financial costs of the treatment and medical care. Communicating concerns and expectations between the partners is a vital point. It allows to avoid misunderstandings, disappointments and unnecessary stress. Both, women and men need time to get used to a new situation and to show good will and understanding to each other which makes it easier to cope with difficulties [6]. Psychological counseling also plays a crucial role in the treatment, helping women to cope with grievance, fight with negative emotions and accept their body.

\section{Problems in physical sphere}

After mastectomy, a lot of physical dysfunctions emerge in patients. Those problems are connected with the continuous need for protection of the upper limb on the operated side of the breast and with specialized physiotherapeutic process [7]. Breast removal results in creating adverse conditions of trunk statics, caused by the lack of balance of its symmetrical parts. It may result in body posture abnormalities such as: stoop, protruding shoulder blades and even in scoliosis.

Mobility limitation on the operated side is very often observed, especially in the shoulder joint. The cause of those limitations is the limb pain during the postoperative period and the occurrence of scarring, frequently observed after radiotherapy. Reduced mobility within the shoulder girdle and limb on the operated side is also affected by the reduced muscle strength which is a natural consequence of a surgical procedure. Surgical site inflammations, sensory disturbances in the fingertips, neuropathies of the operated regions or hematoma may occur [8].

The efficiency of the limb motion is mostly influenced by intra-patient variability, especially a tendency to atrophic scarring. It causes contractures and adhesions in effect and also limited individual's ability to compensate, caused by the decrement of blood vessels and lymph nodes, what is expressed in a tendency to limb swelling [8]. Lymphoedema is the lymph accumulation process occurring in the subcutaneous tissue due to the lymphatic system failure [6].

The complex physiotherapy exercises in patients should be introduced as soon as possible and they should not interfere with the postoperative wound healing process. The rehabilitant teaches and monitors patients' exercises during their hospital stay, so that after discharge from hospital they would be able to comb their hair or dress by themselves. Exercises should be continued once patients return home in a frequent and short manner [9].

Filling up the breast tissue loss by providing an external prosthesis is helpful in regaining self-confidence. Breast prosthesis is a key element of the psychological and physical rehabilitation, which on the one hand, allows to aesthetically cover up the lack of a breast, and on the other hand, has an absolutely crucial health importance. Prothesis that is properly adjusted and implemented right after the healing of the wounds and taking off dressings prevents from trunk statics disorders and spinal curvatures, which may result in slouch, protruding shoulder blade, lowering or lifting a shoulder on the operated side [6].

\section{AIM}

The aim of the study was to identify health concerns of women after a mastectomy.

To fulfill this objective the following questions were investigated:

- Does mastectomy cause physical dysfunctions and limitations for the patient in everyday life?

- How does the breast removal procedure affect the mental state of the patient?

- Is there a link between patient's age, place of residence, the level of education and the way an illness affected her life?

\section{MATERIALS AND METHODS}

The survey was conducted in May 2015 at the Maria Skłodowska-Curie Memorial Cancer Center and Institute of Oncology in Warsaw and at the Warsaw- Ochota Amazon Women Association among 40 women after mastectomy, with the prior consent to participate in the survey.

The research tool used in the study was a questionnaire prepared by researchers which consisted of 28 yes/no questions. The questions were based on a prior literature search and examination. They were intended to collect information regarding the health concerns of women 
after mastectomy. Apart from that, the questions covered demographic data such as age, place of residency, level of education and marital status. Respondents were asked to fill out the questionnaire on their own. No refusals to complete the survey were reported.

Participation in the survey was voluntary and anonymous. Respondents were also informed about the topic of the survey and its use for scientific purposes. The report was of empirical character and was based on the gathered literature, technical publications, Internet sources and on the own conducted research.

The results were subject to the descriptive and statistical analysis. To establish a statistical relationship between analyzed features the Chi-Square Test was used. The determined margin of error was $5 \%$. The probability value $\mathrm{p}<0.05$ was considered statistically significant.

\section{RESULTS}

Respondents were mostly women above 61 years of age (42.5\%). $27.5 \%$ of them were between the age of 51 and $60,20 \%$ between the age of 41 and 50 and the remaining $10 \%$ were between the age of 31 and 41 . The vast majority of women $(77.5 \%)$ were urban dwellers and remaining $22.5 \%$ of surveyed women were rural residents.

The largest group of respondents (42.5\%) were women in which the breast removal procedure was performed within the last year and in $12.5 \%$ of surveyed women the procedure was performed from 1 year to 5 years ago, $20 \%$ of respondents had the procedure from 6 to 10 years ago and the remaining $25 \%$ of women underwent the surgery more than 10 years ago.

The family history of breast cancer was reported in $22.5 \%$ of surveyed, whereas in $77.5 \%$ of them there were no cases of breast cancer reported among relatives.

For the question, how do you perceive an impact of the ongoing disease on your life, $55 \%$ of women responded that the disease changed their life for worse, $35 \%$ of them said that it did not affect their life and $10 \%$ stated that it changed their life for better (fig. 1). The number of $85 \%$ of the respondents confirmed the acceptance of their physical appearance, whereas $15 \%$ of the women declared that they do not accept their look.

For the question concerning the frequency of experienced emotions such as low mood, dejection or sadness, $52.5 \%$ of respondents stated that they experience it at times, $22.5 \%$ pointed the frequent occurrence, while $10 \%$ experienced it very seldom and $15 \%$ did not experience it at all (fig. 2). According to the study, $60 \%$ of women used psychologist services, while the remaining respondents informed that they did not receive such assistance.

The analysis of the data revealed that $90 \%$ of women wore breast prosthesis after the mastectomy. The respondents were asked to evaluate the level of physical fitness and $72.5 \%$ answered that it decreased, while $27.5 \%$ said that it did not change.

For the question, did you take part in rehabilitation during the hospital stay, $77 \%$ of the women confirmed, while $22.5 \%$ of respondents did not participate in such forms of medical assistance.

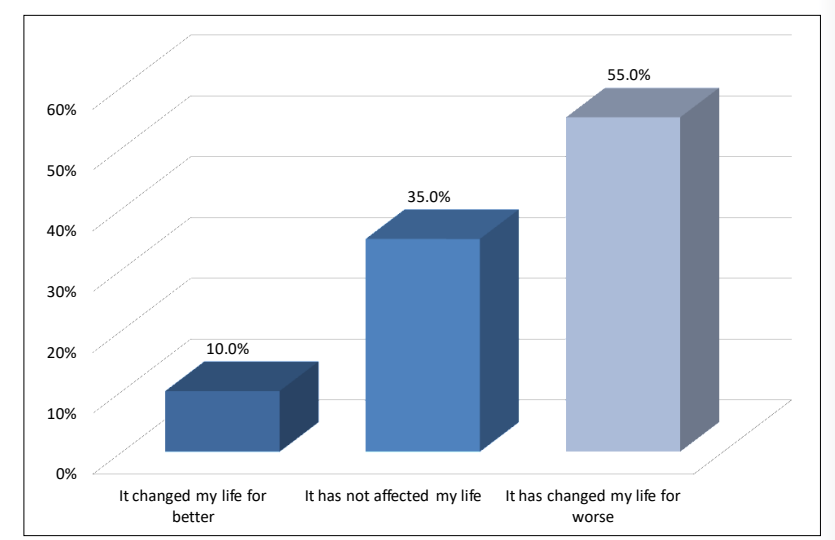

Fig 1. Impact of the disease on the respondent's life.

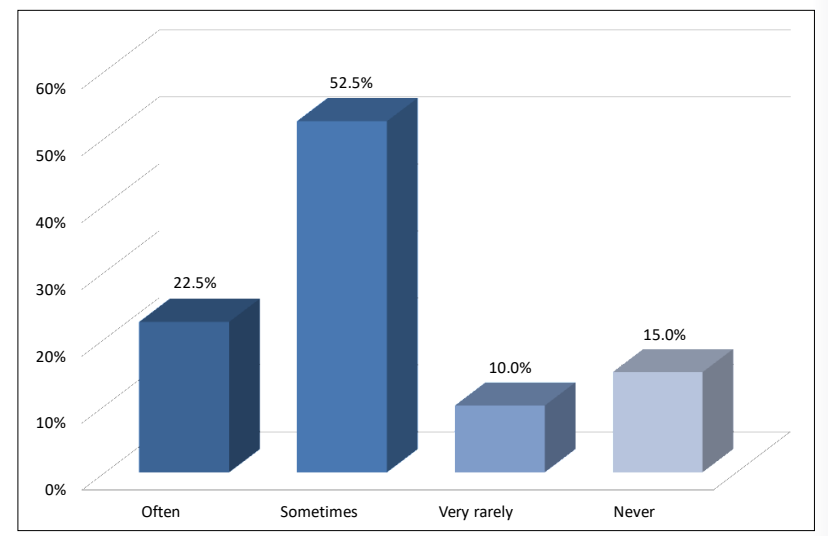

Fig 2. The incidence of such emotions as: low mood, depression, sadness.

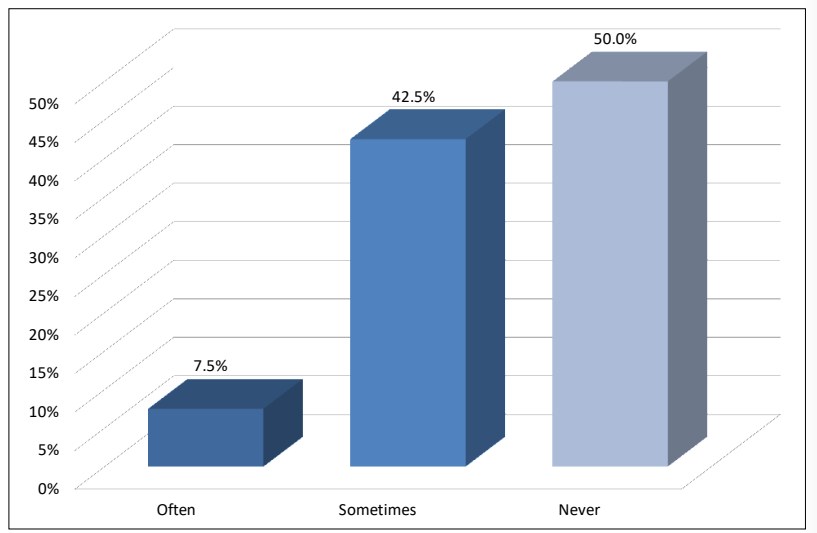

Fig 3. The swelling of the operated limb.

In the half of respondents no swelling of operated limb was reported, $42.5 \%$ reported that it occurred sometimes, while $7.5 \%$ experienced it frequently (fig. 3 ). The vast majority of respondents (75\%) used self lymphatic massage.

Out of all respondents, for the question about an occurrence of pain in the operated area, the most numerous group $(57.5 \%)$ replied that it occurred sometimes, $17.5 \%$ of the surveyed women pointed often occurrence, while $25 \%$ did not point any pain (fig. 4 ).

Limb pain was a frequent problem in $15 \%$ of women, $52.5 \%$ reported that it occurred sporadically, whereas $32.5 \%$ did not face such discomfort. As many as $30 \%$ of the women complained of the restricted mobility of the operated limb, more than a half of respondents (55\%) pointed it occurred rarely and the remaining 15\% did not suffer from it at all (fig. 5). 


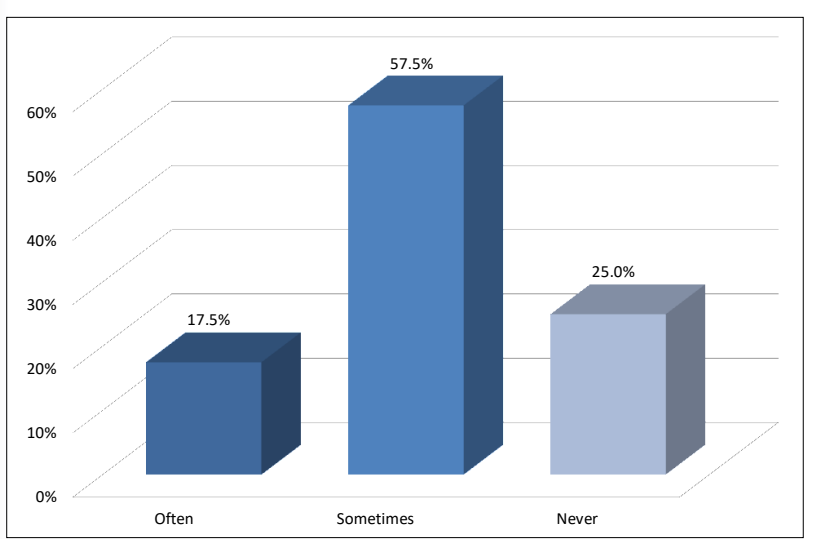

Fig 4. Pain in the operated chest area.

The study revealed no statistically significant relationship between an impact of the disease on the participants' lives and: - age $(\mathrm{p}=0.253)$

- place of residence $(\mathrm{p}=0.656)$

- level of education ( $\mathrm{p}=0.672)$

The vast majority of surveyed patients, regardless of socio-demographic features, admitted that the disease changed their life for worse, as shown in table 1,2 and 3.

Tab. 1. Age and an impact of the disease on the respondents' lives.

\begin{tabular}{|l|c|c|c|c|c|c|}
\hline \multirow{2}{*}{ Age } & \multicolumn{6}{|c|}{ How do you assess an impact of the ongoing disease } \\
on your life? \\
\cline { 2 - 7 } & $\begin{array}{c}\text { It changed my life } \\
\text { for better }\end{array}$ & $\begin{array}{c}\text { It has not } \\
\text { affected my life }\end{array}$ & $\begin{array}{c}\text { It has changed } \\
\text { my life for worse }\end{array}$ \\
\cline { 2 - 7 } & $\mathbf{N}$ & $\%$ & N & $\%$ & N & $\%$ \\
\hline $31-40$ years & 1 & $25.0 \%$ & 0 & $0.0 \%$ & 3 & $75.0 \%$ \\
\hline $41-50$ years & 2 & $25.0 \%$ & 4 & $50.0 \%$ & 2 & $25.0 \%$ \\
\hline $51-60$ years & 0 & $0.0 \%$ & 4 & $36.4 \%$ & 7 & $63.6 \%$ \\
\hline above 60 years & 1 & $5.9 \%$ & 6 & $35.3 \%$ & 10 & $58.8 \%$ \\
\hline Significant & \multicolumn{7}{|c|}{$\lambda^{2}(6)=7.8 ; p>0.05$} \\
\hline
\end{tabular}

Tab. 2. Place of residence and an impact of the disease on the respondents'lives.

\begin{tabular}{|l|c|c|c|c|c|c|}
\hline \multirow{2}{*}{$\begin{array}{c}\text { Place of } \\
\text { residence }\end{array}$} & \multicolumn{6}{|c|}{ How do you assess an impact of the ongoing disease } \\
on your life? \\
\cline { 2 - 7 } & $\begin{array}{c}\text { It changed my } \\
\text { life for better }\end{array}$ & $\begin{array}{c}\text { It has not } \\
\text { affected my life }\end{array}$ & $\begin{array}{c}\text { It has changed } \\
\text { my life for worse }\end{array}$ \\
\cline { 2 - 7 } & $\mathbf{N}$ & $\%$ & $\mathbf{N}$ & $\%$ & $\mathbf{N}$ & $\%$ \\
\hline Town & 3 & $9.7 \%$ & 12 & $38.7 \%$ & 16 & $51.6 \%$ \\
\hline Village & 1 & $11.1 \%$ & 2 & $22.2 \%$ & 6 & $66.7 \%$ \\
\hline Significant & \multicolumn{5}{|c|}{$\lambda^{2}(2)=0.84 ; \mathrm{p}>0.05$} \\
\hline
\end{tabular}

Tab. 3. Level of education and an impact of the disease on the respondents'lives.

\begin{tabular}{|l|c|c|c|c|c|c|}
\hline \multirow{3}{*}{ Education } & \multicolumn{6}{|c|}{ How do you assess an impact of the ongoing disease } \\
on your life?
\end{tabular}

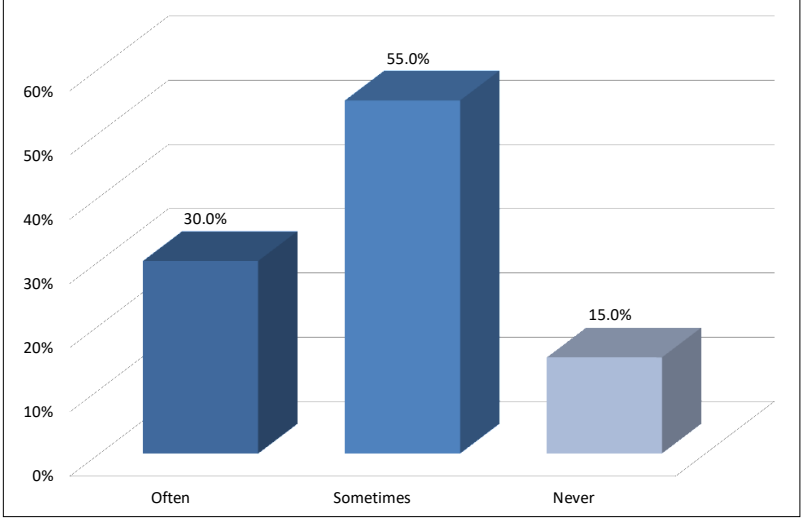

Fig 5. Reduction in mobility of the operated limb.

The statistical analysis also revealed no significant relationship between the time elapsed since the surgery and the acceptance of the physical appearance of respondents $(p=0.566)$, the experience of negative emotions $(p=0.108)$ or the influence of mastectomy on their lives $(p=0.190)$. The majority of respondents, regardless of the date of the surgery, admitted that the disease changed their life for worse and that they experienced low mood sometimes. The detailed results are presented in table 4, 5 .

Tab. 4. The date of the surgery and the acceptance of the physical appearance of the respondents.

\begin{tabular}{|l|c|c|c|c|}
\hline \multirow{2}{*}{$\begin{array}{c}\text { Time since the } \\
\text { mastectomy } \\
\text { procedure }\end{array}$} & \multicolumn{4}{|c|}{$\begin{array}{c}\text { Do you accept your physical appearance after } \\
\text { mastectomy? }\end{array}$} \\
\cline { 2 - 5 } & \multicolumn{2}{|c|}{ Yes, I do } & \multicolumn{2}{c|}{ No, I don't } \\
\cline { 2 - 5 } & N & $\%$ & N & $\%$ \\
\hline Less than a year ago & 16 & $94.1 \%$ & 1 & $5.9 \%$ \\
\hline 1-5 years ago & 4 & $80.0 \%$ & 1 & $20.0 \%$ \\
\hline 6-10 years ago & 6 & $75.0 \%$ & 2 & $25.0 \%$ \\
\hline Over 10 years ago & 8 & $80.0 \%$ & 2 & $20.0 \%$ \\
\hline Significant & \multicolumn{5}{c|}{$\lambda^{2}(3)=2 ; p>0.05$} \\
\hline
\end{tabular}

Tab. 5. The date of the surgery and the occurrence of negative emotions in the respondents.

\begin{tabular}{|c|c|c|c|c|c|c|c|c|}
\hline \multirow{3}{*}{$\begin{array}{c}\text { Time } \\
\text { since the } \\
\text { mastectomy } \\
\text { procedure }\end{array}$} & \multicolumn{8}{|c|}{$\begin{array}{l}\text { How often do you experience emotions such as: } \\
\text { low mood, depression, sadness? }\end{array}$} \\
\hline & \multicolumn{2}{|c|}{ Often } & \multicolumn{2}{|c|}{ Sometimes } & \multicolumn{2}{|c|}{ Very rarely } & \multicolumn{2}{|c|}{ Never } \\
\hline & $\mathbf{N}$ & $\%$ & $\mathrm{~N}$ & $\%$ & N & $\%$ & $\mathbf{N}$ & $\%$ \\
\hline $\begin{array}{l}\text { Less than } \\
\text { a year ago }\end{array}$ & 4 & $23.5 \%$ & 11 & $64.7 \%$ & 1 & $5.9 \%$ & 1 & $5.9 \%$ \\
\hline $1-5$ years ago & 0 & $0.0 \%$ & 2 & $40.0 \%$ & 2 & $40.0 \%$ & 1 & $20.0 \%$ \\
\hline $6-10$ years ago & 1 & $12.5 \%$ & 6 & $75.0 \%$ & 0 & $0.0 \%$ & 1 & $12.5 \%$ \\
\hline $\begin{array}{l}\text { Over } 10 \text { years } \\
\text { ago }\end{array}$ & 4 & $40.0 \%$ & 2 & $20.0 \%$ & 1 & $10.0 \%$ & 3 & $30.0 \%$ \\
\hline Significant & & & & $=$ & & & & \\
\hline
\end{tabular}

The study also found no statistically significant relationship between the occurrence of limb swelling $(p=0.642)$, the pain in the operated area of the chest $(\mathrm{p}=0.477)$ and the type of conducted surgery. The research showed that an emergence of mobility limitation of an operated limb was significantly related to the type of the procedure $(\mathrm{p}=0.011)$. 
In case of a sparing mastectomy, $75 \%$ of the respondents did not suffer from mobility limitation of an arm, while in case of radical and modified radical mastectomy, it was a significant problem (respectively $91.2 \%$ of women after the radical one and $100 \%$ after modified mastectomy reported an occurrence of this complaint).

\section{DISCUSSION}

A struggle with cancer is often a long process, causing stress, having an impact on life and its quality and leading to changes in patient's psychical condition. At all stages of therapy, rehabilitation, progression or the recurrence of the disease, the patient faces a lot of specific challenges. They are related to both, the health condition and to short- as well as long-term side effects of the applied anticancerogenic therapy (among others, effects of chemotherapy or radiotherapy) [10].

Based on own studies, the most numerous groups of surveyed women were the ones with high (47.5\%) and secondary (45\%) education. Married women prevailed (55\%), while non-married accounted for the least (7.5\%). In other authors' works, the highest percentage of respondents $(65.3 \%)$ were married women with secondary education (60\%) [11].

Breast cancer has a great impact on women's dispositions and might cause changes which leave a mark on the whole life. A mastectomy substantially affects emotional condition. Lowering the mood, dejection and sadness were observed in more than half of respondents. The results with similar pattern where obtained by other authors. Wołowicka and Andrzejewski have shown that among the respondents, the feeling of sadness and depression were at the medium level $[12,13]$. Among patients surveyed by Bulse et al., $64.2 \%$ of them pointed out a feeling of sadness and dejection; $21.6 \%$ experienced anxiety, concern and fear; $6.1 \%$ reported depression and $3.2 \%$ impatience [5].

In the studies carried out by Bulse and Rzepe respondents said that the disease affected the course of their life. The vast majority of surveyed women reported a change in their life, and one of them acknowledged that this experience has ruined her life [5]. Based on own studies, it was indicated that in a majority of respondents (55\%) the disease changed their lives for worse, in $35 \%$ had no impact and in $10 \%$ changed their lives for better.

Breast reconstruction surgeries and prosthesis play a major role in improving patients' lives after a mastectomy. Among all of the surveyed women the majority used prosthesis.

The result of the study indicating an acceptance of the body image after mastectomy in respondents seems interesting and significantly differs from the data reported by authors as Fobair or Grajda who demonstrated a link between a treatment and low self-assessment of body image $[14,15]$.

As the literature data indicates, women after mastectomy experience not only body mutilation but also psychological damage which manifest itself in the lack of acceptance and the feeling of incomplete self-worth.
On top of this, the patients suffer from decrease in physical aptitude which worsens the quality of their life. It may also cause lymphoedema and the reduction in mobility of an upper limb. The abovementioned factors pose a major postoperative problem $[16,17]$.

In the performed studies, the majority of women accepted their physical appearance after mastectomy. In the research conducted by Hang [18] and Kulesza-Brończyk [19], the respondents negatively assessed their body image and were unable to reconcile with the loss of feminity.

Another problem occurring in women after mastectomy is lymphoedema in the upper limb which is one of the major complications of the oncological treatment of breast cancer. Chachaj and Małyszczak have investigated the quality of life of women with lymphoedema and showed that its presence causes greater disturbance in psychical state than the lack of a breast. Those women also achieved lower results in the spheres concerning physical and mental functioning. Because of the lack of own body acceptance, they also had problems with social functioning. In comparison to women without this complication, they more often reported pain issues on the operated side, poor sexual functioning and a worse perception of life chances [20]. The own research confirmed the literature data. In $50 \%$ of surveyed women, lymphoedema was reported, in $85 \%$ was the reduction of the mobility of an operated limb. The impairment of functioning and physical aptitude caused by an arm pain was confirmed in $67.5 \%$ of the surveyed women.

\section{CONCLUSIONS}

The carried out study shows that:

1. Mastectomy has a negative impact on women's psychological well-being. For many of them, it was accompanied with low mood, feeling of dejection and sadness.

2. Women's day-to-day functioning and physical aptitude is impaired by pain and lymphoedema along with the reduced mobility of operated limb.

3. In the opinion of the vast majority of patients after breast cancer surgery, the disease changes life for worse regardless of age, place of residence or level of education.

4. The time elapsed since the performed surgery has no significant relationship with women's experience of negative emotions and decreased quality of life. 


\section{Problemy zdrowotne kobiet po mastektomii}

\section{WPROWADZENIE}

Nowotwór piersi jest jednym z najczęściej występujących nowotworów złośliwych u kobiet w Polsce. Zapada na niego około 16000 Polek rocznie, co stanowi poważny problem społeczny [1,2]. Pomimo, iż liczba wyleczeń rośnie, nowotwór nadal uważany jest za ciężką i nieuleczalną chorobę [3]. Badanie piersi oraz badania profilaktyczne pozwalają na wczesne wykrycie zmian nowotworowych i zastosowanie odpowiedniego leczenia. Niestety w wielu przypadkach po wykryciu choroby metody takie jak chemioterapia, hormonoterapia czy radioterapia nie są $\mathrm{w}$ pełni skuteczne i często konieczna staje się mastektomia.

Amputacja piersi jest zabiegiem, który pociąga za sobą wiele skutków ubocznych. Powoduje gorsze funkcjonowanie w sferze fizycznej i psychicznej. Wywołuje też niedostosowanie społeczne i zawodowe, związane z pogorszeniem wizerunku własnego ciała [4].

\section{Problemy w sferze psychicznej}

Piersi są dla kobiet symbolem kobiecości i macierzyństwa. Ich utrata przyczynia się do wystąpienia dużego stresu, uczucia wstydu, przewlekłego obniżenia nastroju czy depresji $[4,5]$. Następstwa psychiczne mają często podłoże rodzinne, zawodowe, a także estetyczne. Następstwa rodzinne związane są z lękiem przed śmiercią, osieroceniem dzieci czy utratą partnera. Z kolei zawodowe wiążą się z możliwością utraty pracy i pozycji społecznej. Następstwa estetyczne to głównie niska samoocena, wynikająca ze spadku atrakcyjności fizycznej.

$\mathrm{W}$ walce $\mathrm{z}$ chorobą istotne jest wsparcie psychiczne bliskich osób. Rodzina opiekuje się chorym w razie niedyspozycji fizycznej, uczestniczy w kosztach finansowych leczenia i opieki. Najważniejsze, aby partnerzy potrafili rozmawiać ze sobą o własnych oczekiwaniach i obawach. Pozwala to wtedy na uniknięcie nieporozumień, rozczarowań i niepotrzebnego stresu. Zarówno kobieta, jak i mężczyzna potrzebują czasu na oswojenie się z nową sytuacją, a okazywana przez obie strony dobra wola i zrozumienie ułatwiają poradzenie sobie z ewentualnymi trudnościami [6]. Znaczącą rolę odgrywają również wizyty u psychologa, które pomagają kobietom uporać się z poczuciem krzywdy, zwalczyć negatywne emocje i zaakceptować swoje ciało.

\section{Problemy w sferze fizycznej}

Po mastektomii u pacjentek pojawia się wiele dysfunkcji fizycznych. Związane są one z potrzebą ciągłej ochrony kończyny górnej po stronie operowanej piersi oraz stosowania specjalistycznego postępowania fizjoterapeutycznego [7]. Amputacja piersi stwarza niekorzystne warunki statyki tułowia, spowodowane brakiem zrównoważenia jego symetrycznych części. Następstwem tego mogą być zaburzenia postawy: przygarbienie, odstawanie łopatek, a nawet skrzywienie boczne kręgosłupa.

Bardzo często obserwowane jest również ograniczenie zakresu ruchów po stronie operowanej, szczególnie w stawie ramiennym. Powodem tych ograniczeń jest ból kończyny w okresie pooperacyjnym oraz występujące zmiany bliznowate, szczególnie obserwowane po stosowaniu radioterapii. Na ograniczenie ruchomości w obrębie pasa barkowego oraz kończyny strony operowanej, wpływa także zmniejszenie siły mięśni, które jest naturalnym następstwem zabiegu operacyjnego. Mogą pojawić się również stany zapalne miejsc pooperacyjnych, zaburzenia czucia w opuszkach palców, neuropatie w okolicy operowanej czy krwiak [8].

Na sprawność kończyny wpływają w dużej mierze właściwości osobnicze, zwłaszcza skłonność do bliznowacenia przerostowego. W efekcie powoduje ona przykurcze i zrosty, oraz ograniczoną zdolność osobniczą do kompensacji, spowodowaną ubytkami naczyń i węzłów chłonnych, co wyraża się skłonnością do powstawania obrzęku kończyny [8]. Obrzęk limfatyczny to proces gromadzenia się chłonki w tkance podskórnej, który wynika z niewydolności układu chłonnego [6].

Kompleksowe ćwiczenia rehabilitacyjne u pacjentek po operacji powinny być wdrożone jak najwcześniej i nie powinny one zaburzać gojenia rany pooperacyjnej. Rehabilitant uczy i nadzoruje wykonywanie ćwiczeń w czasie pobytu kobiety w szpitalu, aby po wypisaniu do domu mogła ona bez przeszkód uczesać się czy ubrać. Ćwiczenia powinny być kontynuowane po powrocie do domu, wykonywane często i krótkotrwale [9].

W odzyskaniu pewności siebie pomocne jest uzupełnienie ubytku piersi poprzez zaopatrzenie w zewnętrzną protezę. Proteza jest ważnym elementem rehabilitacji psychicznej i fizycznej, gdyż z jednej strony pozwala w sposób estetyczny zatuszować brak piersi, a z drugiej ma bezwzględne znaczenie zdrowotne. Odpowiednio dobrana, zastosowana tuż po zagojeniu się ran i zdjęciu opatrunków, zapobiega zaburzeniom statyki tułowia oraz skrzywieniom kręgosłupa, które moga prowadzić do przygarbienia, odstawania łopatki, obniżenia lub uniesienia barku strony operowanej [6].

\section{CEL PRACY}

Celem badań była identyfikacja problemów zdrowotnych kobiet po mastektomii.

Dla realizacji celu postanowiono sprawdzić:

- Czy mastektomia wywołuje dysfunkcje fizyczne i ograniczenia w życiu codziennym?

- Jak zabieg amputacji piersi wpływa na psychikę chorych?

- Czy istnieje związek pomiędzy wiekiem, miejscem zamieszkania, wykształceniem badanych, a tym jak choroba wpłynęła na ich życie?

\section{MATERIAŁ I METODYKA}

Badanie zostało przeprowadzone w maju 2015 roku w Centrum Onkologii - Instytut im. Marii SkłodowskiejCurie w Warszawie oraz w Stowarzyszeniu „Amazonki” 
Warszawa - Ochota wśród 40 kobiet po mastektomii, po uprzednim wyrażeniu przez nie zgody na udział $\mathrm{w}$ ankiecie.

Narzędziem badawczym, wykorzystanym w pracy był autorski kwestionariusz ankiety, składający się z 28 pytań typu zamkniętego. Pytania zostały ułożone w oparciu o wcześniejszą analizę literatury. Miały one na celu zebranie informacji na temat problemów zdrowotnych kobiet po mastektomii. Poza tym pytania dotyczyły danych demograficznych, takich jak wiek, miejsce zamieszkania, wykształcenie oraz stan cywilny. Badane poproszone zostały o samodzielne wypełnienie ankiety. Nie odnotowano odmów ich wypełnienia.

Udział w badaniu miał charakter dobrowolny i anonimowy, a respondentki zostały poinformowane o temacie ankiety oraz o wykorzystaniu wyników badań do celów naukowych. Praca miała charakter empiryczny, powstała na podstawie zebranej literatury, fachowych publikacji, źródel internetowych oraz przeprowadzonych badań własnych.

Badania poddano analizie opisowej oraz statystycznej. Do zbadania zależności statystycznej pomiędzy analizowanymi cechami użyto testu chi kwadrat. Przyjęto 5\% ryzyka błędu wnioskowania. Wartość prawdopodobieństwa $\mathrm{p}<0,05$ uznano za statystycznie istotną.

\section{WYNIKI}

Badane to w większości kobiety powyżej 61 roku życia (42,5\%). Odnotowano $27,5 \%$ osób w przedziale wiekowym 51-60 lat, w przedziale 41-50 lat znalazło się 20\%, pozostałe $10 \%$ stanowią osoby w wieku 31-40 lat. Zdecydowana większość kobiet (77,5\%) okazała się mieszkankami miast, pozostałe 22,5\% ankietowanych mieszka na wsi.

Najliczniejszą grupę respondentek $(42,5 \%)$ tworzyły kobiety, u których zabieg usunięcia piersi został przeprowadzony w przeciągu ostatniego roku, u 12,5\% ankietowanych miał on miejsce od 1 roku do 5 lat temu, $20 \%$ to osoby, u których zabieg odbył się 6 do 10 lat temu, zaś pozostałe $25 \%$ to kobiety, które były poddane operacji ponad 10 lat temu.

Rodzinne występowanie nowotworu piersi stwierdziło $22,5 \%$ ankietowanych, natomiast u $77,5 \%$ nie odnotowano przypadków zachorowań na ten rodzaj nowotworu w gronie najbliższych.

Na pytanie Jak ocenia Pani wpływ obecnej choroby na swoje życie, 55\% kobiet odpowiedziało, że choroba zmieniła ich życie na gorsze, 35\% stwierdziło, że nie wywarła wpływu na ich życie, a 10\% uznało, że choroba zmieniła ich życie na lepsze (ryc. 1). Akceptację swojego wyglądu fizycznego po zabiegu potwierdziło $85 \%$ respondentek, natomiast $15 \%$ kobiet zadeklarowało, że nie akceptuje swojego wyglądu.

W pytaniu o częstość towarzyszenia emocji takich jak obniżenie nastroju, przygnębienie czy smutek 52,5\% badanych stwierdziło, że doświadcza ich czasami, 22,5\% wskazało na ich częste występowanie, u $10 \%$ pojawiały się one bardzo rzadko, zaś u 15\% nie występowały (ryc. 2). Według badań, z usług psychologa korzystało $60 \%$ kobiet, natomiast pozostałe respondentki poinformowały, że nie korzystały z takiej pomocy.

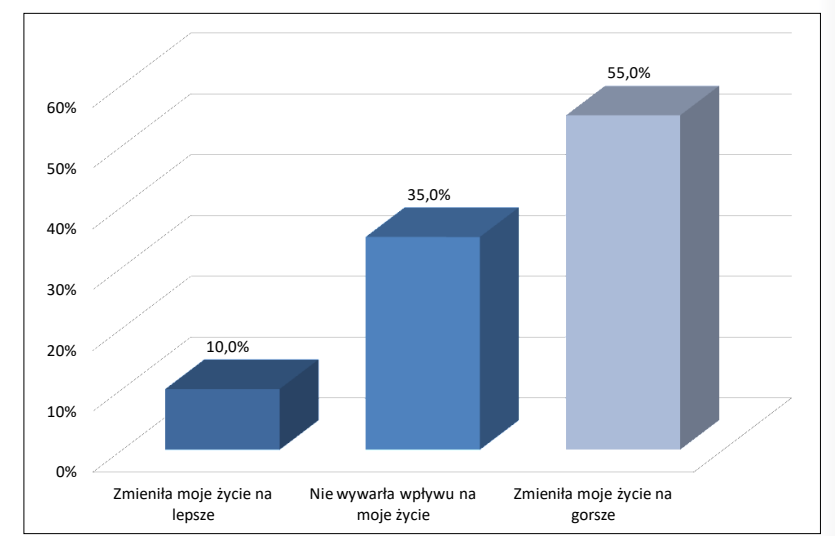

Ryc 1. Wpływ choroby na życie.

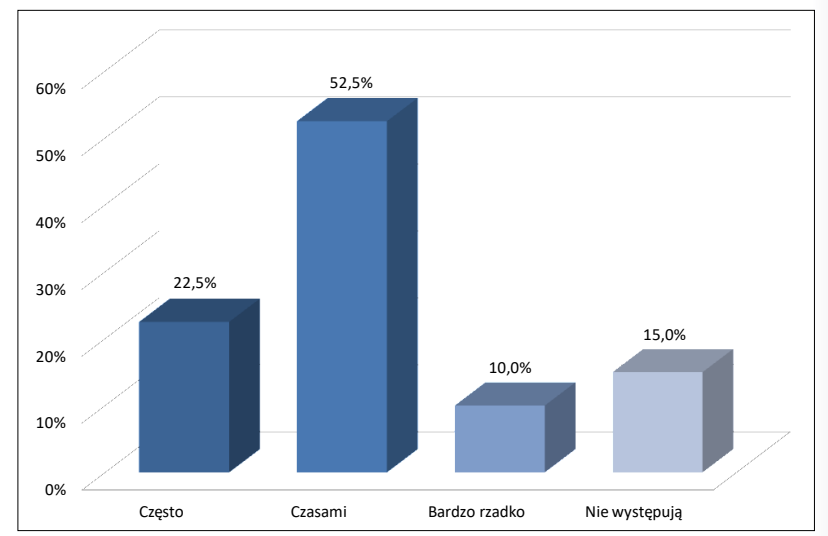

Ryc 2. Częstość występowania emocji: obniżenia nastoju, przygnębienia, smutku.

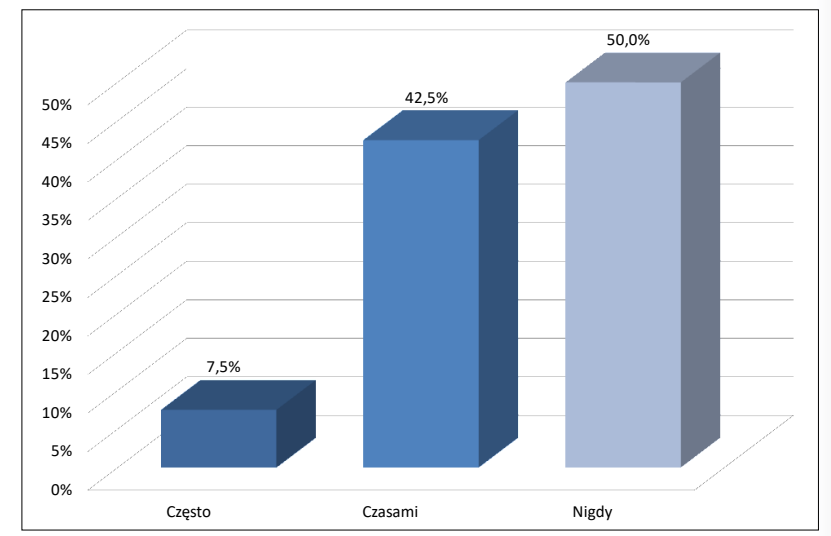

Ryc 3. Obrzęk kończyny operowanej.

Analiza danych wykazała, że 90\% kobiet po zabiegu mastektomii nosiło protezę piersi. Ankietowane poproszone o ocenę sprawności po operacji w 72,5\% odpowiedziały, że sprawność zmniejszyła się, w 27,5\% uznały, że nie uległa ona zmianie.

$\mathrm{Na}$ pytanie czy korzystała pani z rehabilitacji w czasie pobytu w szpitalu 77\% kobiet potwierdziło, że korzystało, natomiast $22,5 \%$ badanych nie uczestniczyło w tego rodzaju formach zdrowotnych.

$\mathrm{U}$ połowy ankietowanych nigdy nie wystąpił obrzęk kończyny operowanej, $42,5 \%$ osób zgłosiło, że występował czasami, natomiast u 7,5\% często (ryc. 3). Zdecydowana większość respondentek (75\%) stosowała automasaż limfatyczny.

Spośród wszystkich ankietowanych na pytanie o występowanie bólu w operowanej okolicy, najliczniejszą grupę 
57,5\% tworzą osoby, które stwierdziły, że ból występował czasami, 17,5\% respondentek zaznaczyło, że często, 25\% wskazało na brak bólu (ryc. 4).

Ból kończyny był częstym problemem u 15\% kobiet, o sporadycznym odczuciu bólu mówiło 52,5\% ankietowanych, z kolei 32,5\% nigdy z tą dolegliwością się nie spotkało.

Na częste problemy z ograniczeniem ruchomości kończyny operowanej skarżyło się 30\% kobiet, ponad połowa badanych (55\%) wskazała na rzadkie problemy w tym zakresie, pozostałe $15 \%$ nie doświadczyło tej dysfunkcji (ryc. 5).

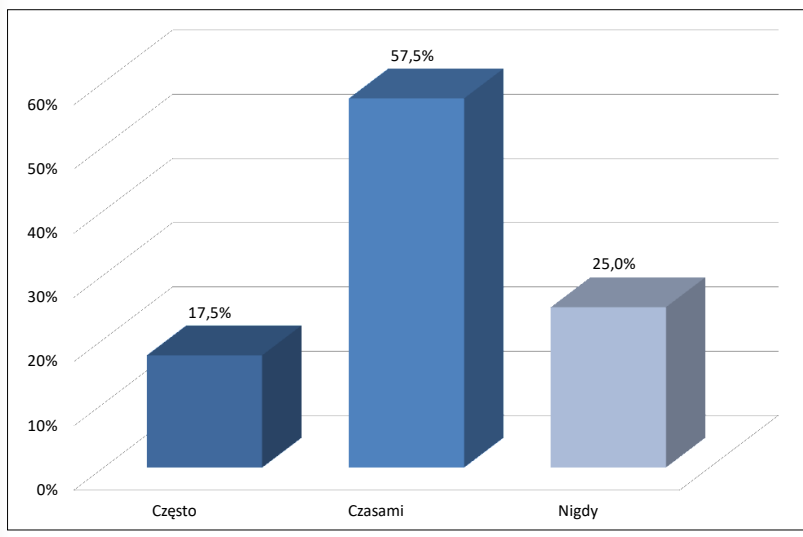

Ryc 4. Ból w operowanej okolicy klatki piersiowej.

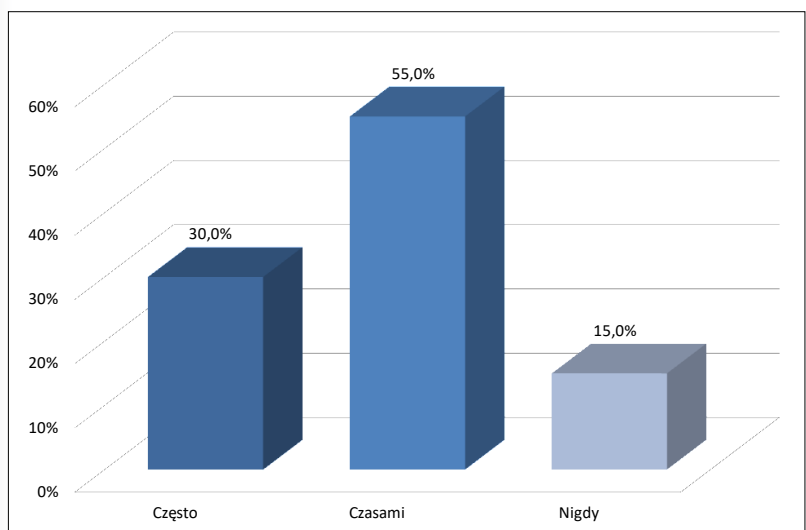

Ryc 5. Ograniczenia zakresu ruchów kończyny operowanej.

Badania nie wykazały istotnej statystycznie zależności pomiędzy wpływem choroby na życie, a:

- wiekiem ( $\mathrm{p}=0,253)$;

- miejscem zamieszkania ( $\mathrm{p}=0,656)$;

- wykształceniem $(\mathrm{p}=0,672)$.

Zdecydowana większość badanych bez względu na czynniki socjodemograficzne przyznała, iż choroba zmieniła ich życie na gorsze, co przedstawiają kolejno tabele 1,2 i 3.

Analiza statystyczna nie wykazała również istotnej zależności między czasem jaki minął od zabiegu chirurgicznego, a akceptacją wyglądu fizycznego przez ankietowane $(\mathrm{p}=0,566)$, doświadczaniem występowania negatywnych emocji $(\mathrm{p}=0,108)$ oraz wpływem mastektomii na ich życie $(\mathrm{p}=0,190)$. Większość ankietowanych bez względu na termin operacji przyznała, że choroba zmieniła życie na gorsze oraz że czasami zaznawały odczucia obniżonego nastroju. Szczegółowe wyniki przedstawiono w tabelach 4, 5 .
Tab. 1. Wiek, a wpływ choroby na życie badanych osób.

\begin{tabular}{|l|c|c|c|c|c|c|}
\hline \multirow{3}{*}{ Wiek } & \multicolumn{6}{|c|}{ Jak ocenia Pani wpływ obecnej choroby na swoje życie? } \\
\cline { 2 - 7 } & $\begin{array}{c}\text { Zmieniła moje } \\
\text { życie na lepsze }\end{array}$ & $\begin{array}{c}\text { Nie wywarła } \\
\text { wpływu } \\
\text { na moje życie }\end{array}$ & $\begin{array}{c}\text { Zmieniła moje } \\
\text { życie na gorsze }\end{array}$ \\
\cline { 2 - 7 } & $\mathbf{N}$ & $\%$ & $\mathbf{N}$ & $\%$ & $\mathbf{N}$ & $\%$ \\
\hline $31-40$ lat & 1 & $25,0 \%$ & 0 & $0,0 \%$ & 3 & $75,0 \%$ \\
\hline 41-50 lat & 2 & $25,0 \%$ & 4 & $50,0 \%$ & 2 & $25,0 \%$ \\
\hline 51-60 lat & 0 & $0,0 \%$ & 4 & $36,4 \%$ & 7 & $63,6 \%$ \\
\hline powyżej60 lat & 1 & $5,9 \%$ & 6 & $35,3 \%$ & 10 & $58,8 \%$ \\
\hline Istotność & \multicolumn{7}{|c|}{$\lambda^{2}(6)=7,8 ; p>0,05$} \\
\hline
\end{tabular}

Tab. 2. Miejsce zamieszkania, a wpływ choroby na życie badanych osób.

\begin{tabular}{|l|c|c|c|c|c|c|}
\hline \multirow{2}{*}{$\begin{array}{c}\text { Miejsce } \\
\text { zamieszkania }\end{array}$} & \multicolumn{4}{|c|}{ Jak ocenia Pani wpływ obecnej choroby na swoje życie? } \\
\cline { 2 - 7 } & $\begin{array}{c}\text { Zmieniła moje } \\
\text { życie na lepsze }\end{array}$ & $\begin{array}{c}\text { Nie wywarła } \\
\text { wpływu na moje } \\
\text { życie }\end{array}$ & $\begin{array}{c}\text { Zmieniła moje } \\
\text { życie na gorsze }\end{array}$ \\
\cline { 2 - 7 } & $\mathbf{N}$ & $\%$ & $\mathbf{N}$ & $\%$ & $\mathbf{N}$ & $\%$ \\
\hline Miasto & 3 & $9,7 \%$ & 12 & $38,7 \%$ & 16 & $51,6 \%$ \\
\hline Wiés & 1 & $11,1 \%$ & 2 & $22,2 \%$ & 6 & $66,7 \%$ \\
\hline Istotność & \multicolumn{6}{|c|}{$\lambda^{2}(2)=0,84 ; p>0,05$} \\
\hline
\end{tabular}

Tab. 3. Wykształcenie, a wpływ choroby na życie badanych osób.

\begin{tabular}{|l|c|c|c|c|c|c|}
\hline \multirow{2}{*}{ Wykształcenie } & \multicolumn{3}{|c|}{ Jak ocenia Pani wpływ obecnej choroby na swoje życie? } \\
\cline { 2 - 7 } & $\begin{array}{c}\text { Zmieniła moje } \\
\text { życie na lepsze }\end{array}$ & $\begin{array}{c}\text { Nie wywarła } \\
\text { wpływu na moje } \\
\text { życie }\end{array}$ & $\begin{array}{c}\text { Zmieniła moje } \\
\text { życie na gorsze }\end{array}$ \\
\cline { 2 - 7 } & $\mathbf{N}$ & $\%$ & $\mathbf{N}$ & $\%$ & $\mathbf{N}$ & $\%$ \\
\hline Zawodowe & 0 & $0 \%$ & 1 & $33,3 \%$ & 2 & $66,7 \%$ \\
\hline Średnie & 1 & $5,6 \%$ & 8 & $44,4 \%$ & 9 & $50,0 \%$ \\
\hline Wyższe & 3 & $15,8 \%$ & 5 & $26,3 \%$ & 11 & $57,9 \%$ \\
\hline Istotność & \multicolumn{7}{|c|}{$\lambda^{2}(4)=2,35 ; \mathrm{p}>0,05$} \\
\hline
\end{tabular}

Tab. 4. Termin wykonanego zabiegu, a akceptacja wyglądu fizycznego przez badane osoby.

\begin{tabular}{|l|c|c|c|c|}
\hline \multirow{2}{*}{$\begin{array}{c}\text { Czas od zabiegu } \\
\text { usunięcia piersi }\end{array}$} & \multicolumn{4}{|c|}{$\begin{array}{c}\text { Czy akceptuje Pani swój wygląd fizyczny } \\
\text { po mastektomii? }\end{array}$} \\
\cline { 2 - 5 } & Tak, akceptuję w pełni & \multicolumn{2}{c|}{ Nie akceptuję } \\
\cline { 2 - 5 } & N & $\%$ & N & $\%$ \\
\hline Mniej niż rok & 16 & $94,1 \%$ & 1 & $5,9 \%$ \\
\hline 1-5 lat temu & 4 & $80,0 \%$ & 1 & $20,0 \%$ \\
\hline 6-10 lat temu & 6 & $75,0 \%$ & 2 & $25,0 \%$ \\
\hline Ponad 10 lat temu & 8 & $80,0 \%$ & 2 & $20,0 \%$ \\
\hline Istotność & \multicolumn{5}{|c|}{$\lambda^{2}(3)=2 ; p>0,05$} \\
\hline
\end{tabular}

Tab. 5. Termin wykonanego zabiegu, a występowanie negatywnych emocji u ankietowanych.

\begin{tabular}{|l|c|c|c|c|c|c|c|c|}
\hline \multirow{2}{*}{$\begin{array}{c}\text { Czas od } \\
\text { zabiegu } \\
\text { usunięcia } \\
\text { piersi }\end{array}$} & \multicolumn{6}{|c|}{$\begin{array}{c}\text { Jak często towarzyszą Pani takie emocje jak: } \\
\text { obnizenie nastroju, przygnębienie, smutek? }\end{array}$} \\
\cline { 2 - 9 } & \multicolumn{2}{|c|}{ Często } & \multicolumn{2}{c|}{ Czasami } & $\begin{array}{c}\text { Bardzo } \\
\text { rzadko }\end{array}$ & $\begin{array}{c}\text { Nie } \\
\text { występują }\end{array}$ \\
\cline { 2 - 9 } & N & $\%$ & N & $\%$ & N & $\%$ & N & $\%$ \\
\hline Mniej niż rok & 4 & $23,5 \%$ & 11 & $64,7 \%$ & 1 & $5,9 \%$ & 1 & $5,9 \%$ \\
\hline 1-5 lat temu & 0 & $0,0 \%$ & 2 & $40,0 \%$ & 2 & $40,0 \%$ & 1 & $20,0 \%$ \\
\hline 6-10 lat temu & 1 & $12,5 \%$ & 6 & $75,0 \%$ & 0 & $0,0 \%$ & 1 & $12,5 \%$ \\
\hline $\begin{array}{l}\text { Ponad 10 lat } \\
\text { temu }\end{array}$ & 4 & $40,0 \%$ & 2 & $20,0 \%$ & 1 & $10,0 \%$ & 3 & $30,0 \%$ \\
\hline Istotność & \multicolumn{7}{|c|}{$\lambda^{2}(9)=14,4 ; p>0,05$} \\
\hline
\end{tabular}


Nie okazała się także istotna statystycznie zależność między występowaniem obrzęku kończyny $(\mathrm{p}=0,642)$ oraz bólu w operowanej okolicy klatki piersiowej $(p=0,477)$, a rodzajem przeprowadzonej operacji.

W badaniach wykazano, że pojawianie się ograniczeń zakresu ruchomości kończyny operowanej było istotnie zależne od charakteru zabiegu ( $\mathrm{p}=0,011)$.

W przypadku zabiegu oszczędzającego $75 \%$ ankietowanych nigdy nie zaznała ograniczeń ruchomości ręki, zaś w radykalnej mastektomii i zmodyfikowanej radykalnej mastektomii był to znaczący problem (kolejno 91,2\% kobiet po radykalnej i $100 \%$ po zmodyfikowanej mastektomii zgłosiło wystąpienie tej dolegliwości).

\section{DYSKUSJA}

Zmaganie się z chorobą nowotworową jest często procesem długotrwałym, wywołującym stres, mającym wpływ na zmianę dotychczasowego sposobu życia i jego jakości oraz prowadzącym do zmian w psychice chorych. $\mathrm{Na}$ wszystkich etapach terapii, rehabilitacji, progresji czy nawrotu choroby, pacjent spotyka się $\mathrm{z}$ wieloma specyficznymi problemami. Dotyczą one zarówno stanu zdrowia, jak i krótkotrwałych oraz odległych skutków ubocznych zastosowanej terapii przeciwnowotworowej (m.in. po chemioterapii, radioterapii) [10].

$\mathrm{Na}$ podstawie badań własnych, wśród kobiet najliczniejszą grupę stanowiły osoby mające wykształcenie wyższe 47,5\% i średnie 45\%. Przeważały głównie kobiety zamężne 55\%, natomiast najmniej było panien $7,5 \%$. U innych autorów największy procent badanych $(65,3 \%)$ tworzyły mężatki z wykształceniem średnim (60\%) [11].

Rak piersi ma ogromny wpływ na usposobienie kobiet, może powodować zmiany, które pozostawiają trwały ślad na całe życie. Mastektomia wpływa znacząco na stan emocjonalny. Obniżenie nastroju, przygnębienie oraz smutek odnotowano u ponad połowy ankietowanych. Wyniki o podobnym przekroju uzyskali także inni autorzy. Wołowicka oraz Andrzejewski wykazali, iż wśród badanych na poziomie średnim występowały uczucia smutku, przygnębienia $[12,13]$. Wśród badanych przez Bulse i wsp. 64,2\% osób wskazało występowanie smutku i przygnębienia; $21,6 \%$ osób lęk, obawę i strach, na depresje skarżyło się $6,1 \%$ ankietowanych, na zniecierpliwienie 3,2\% [5].

W badaniach przeprowadzonych przez Bulse i Rzepe ankietowane stwierdziły, że choroba wpłynęła na ich życie. Zdecydowana większość respondentek wyraziła przekonanie o dokonaniu w życiu zmiany, zaś jedna $\mathrm{z}$ badanych przyznała, że to doświadczenie zrujnowało jej życie [5]. Według opracowania badań własnych wykazano, że u większości ankietowanych (55\%) choroba zmieniła ich życie na gorsze, u 35\% nie wywarła wpływu na życie, zaś u $10 \%$ zmieniła je na lepsze.

W poprawie jakości życia pacjentek po mastektomii bardzo pomocne są operacje odtwórcze bądź protezowanie piersi. Spośród wszystkich ankietowanych kobiet po mastektomii znaczna większość korzystała z protezy.

Interesujący wydaje się wynik badania, który świadczy o akceptacji wizerunku własnego ciała po mastektomii wśród badanych, co znacząco różni się od doniesień autorów Fobair czy Grajda, gdzie wykazano zależność pomiędzy leczeniem, a niską samooceną obrazu ciała [14, 15].

Jak podają dane w literaturze, kobiety po amputacji doświadczają nie tylko okaleczenia ciała, ale również urazu psychicznego, który przejawia się brakiem akceptacji i odczuciem niepełnej wartości. Dochodzi do tego również niewydolność fizyczna, powodująca pogorszenie jakości życia. Wiąże się ona z możliwością wystąpienia obrzęku limfatycznego oraz z ograniczeniem ruchomości kończyny górnej. Wymienione czynniki stanowią główny problem pooperacyjny [16,17].

W przeprowadzonych badaniach znacząca większość kobiet zaakceptowała wygląd fizyczny po mastektomii. W badaniach Hanga [18] oraz Kuleszy- Brończyk [19] respondentki negatywnie oceniły obraz własnego ciała, nie mogąc pogodzić się z utratą kobiecości.

Kolejnym problemem występującym u kobiet po mastektomii jest obrzęk limfatyczny kończyny górnej, jedno z najpoważniejszych powikłań leczenia onkologicznego raka piersi. Autorzy Chachaj i Małyszczak, badając jakość życia kobiet z obrzękiem wykazali, że jego obecność wywołuje większe zaburzenia w obszarze psychiki niż brak piersi. Kobiety te osiągnęły także niższe wartości w sferach, dotyczących funkcjonowania emocjonalnego i fizycznego. Poprzez brak akceptacji własnego ciała miały także trudności w funkcjonowaniu społecznym. W porównaniu z kobietami niedotkniętymi tą dolegliwością znacznie częściej uskarżały się na problemy bólowe strony operowanej, gorsze funkcjonowanie seksualne oraz gorszą wizję perspektyw życiowych [20]. Badania własne potwierdziły dane pojawiające się w literaturze, u 50\% badanych kobiet wystąpił obrzęk limfatyczny, zaś u 85\% doszło do ograniczenia ruchomości kończyny operowanej. Upośledzenie funkcjonowania i sprawności fizycznej spowodowane bólem ręki potwierdziło się u $67,5 \%$ kobiet.

\section{WNIOSKI}

Z przeprowadzonych badań wynika, że:

1. Zabieg mastektomii ma negatywny wpływ na psychikę kobiet. Wielu z nich towarzyszy obniżony nastrój, odczucie przygnębienia i smutku.

2. Codzienne funkcjonowanie oraz sprawność fizyczną kobiet po mastektomii upośledzają: ból i obrzęk ręki oraz ograniczenia zakresu ruchów kończyny operowanej.

3. W odczuciu zdecydowanej większości osób po operacji raka piersi choroba zmienia życie na gorsze, przy czym jest to niezależne od ich wieku, miejsca zamieszkania i wykształcenia.

4. Czas jaki upłynął od przeprowadzonego zabiegu nie ma istotnego związku z doświadczaniem przez kobiety negatywnych emocji i pogorszeniem jakości życia. 


\section{PIŚMIENNICTWO/REFERENCES}

1. Murawa D, Dyzmann- Sroka A, Kycler W. i wsp. ABC raka piersi. Wielkopolskie Centrum Onkologii; 2010.

2. Jassem J, Krzakowski M. Rak piersi. Praktyczny przewodnik dla lekarzy. Gdańsk: Via Medica; 2014; s. 2-8.

3. Malicka I, Szczepańska J, Anioł K i wsp. Zaburzenia nastroju i strategie przystosowania do choroby u kobiet leczonych operacyjnie z powodu nowotworu piersi i narządów rodnych. Wspolczesna 0nkol. 2009; 13 (1): 41-45.

4. Zegarski W, Głowacka I, Ostrowska Ż. Ocena jakości życia kobiet po mastektomii na podstawie standardowych kwestionariuszy: QLQ-C30 i QLQ -BR23. Nowotwory. 2010; 60 (6): 532-535.

5. Bulsa M, Rzepa T, Foszczyńska - Kłoda M i wsp. Stan psychiczny kobiet po mastektomii. Post Psychiatr Neurol. 2002; 11: 55-70.

6. Tchórzewska H. Rehabilitacja kobiet leczonych z powodu raka piersi. Poradnik. Warszawa: Federacja Stowarzyszeń Amazonki; 2007, s 10-39.

7. Kamusińska E, Ciosek M, Karwat I.Znaczenie rehabilitacji w leczeniu raka piersi. Stud Med. 2014; 30 (3): 214-220.

8. Mika K. Po odjęciu piersi. Warszawa: PZWL; 2005, s. 23-24.

9. Woźniewski M, Kornafel J. Rehabilitacja w onkologii. Wrocław: Elsevier Urban \& Partner; 2010, s. 190.

10. Irzmańska- Hudziak A, Szadowska- Szlachetka Z, Charzyńska- Gula M, Chabros S. Występowanie objawów ubocznych leczenia cytostatykami a otrzymane wsparcie przez kobiety z rakiem piersi. J Health Sci. 2014; 4(15): 42-52.
11. Bergman P, Nowacka -Chiari E. Charakterystyka społeczno-środowiskowa kobiet po mastektomii. Fizjoterapia. 1997; 7: 24-26.

12. Wołowicka L (red): Jakość życia w naukach medycznych. Poznań: Akademia Medyczna; 2002.

13. Andrzejewski W, Kassolik K, Ochrymowicz M i wsp. Ocena jakości życia kobiet po mastektomii, zrzeszonych w Klubie Amazonek. Fizjoter Pol. 2008; 8: 51-64.

14. Fobair P, Stewart SL, Chang $S$, et al. Body image and sexual problems in young women with breast cancer. Psychooncology 2006; 15: 579-94.

15. Grajda T, Grodecka-Gazdecka S. Czynniki wpływające na jakość życia kobiet leczonych z powodu raka piersi. Przegl Ginekol Poł 2005; 5: 115-120.

16. Tchórzewska H. Rehabilitacja w leczeniu raka piersi. [w:] Pawlicki M, red: Rak piersi - nowe nadzieje i możliwości leczenia. Bielsko-Biała: Wyd. L-medica Press; 2002, s. 107.

17. Weitzner M.A. Funkcjonowanie psychospołeczne i jakość życia chorych na nowotwory gruczołu piersiowego. [w]: Meyza J, red: Jakość życia w chorobie nowotworowej. Warszawa: Wyd. Centrum Onkologii, Instytut M. SkłodowskiejCurie; 1997, s. 225-248

18. Hang J i wsp. Quality of life and satisfaction after breast cancer operations. Arch Gynecol Obstet. 2010; 282: 75-82.

19. Kulesza - Brończyk B i wsp. Jakość życia kobiet po leczeniu operacyjnym raka sutka. Zdr Publ. 2009; 119 (3): 293-297.

20. Chachaj A, Małyszczak K, Lukas Ji wsp. Jakośćżycia kobiet z obrzękiem limfatycznym kończyny górnej po leczeniu raka piersi. Współcz Onkol. 2007; 11: 444-448.

Praca przyjęta do druku/Manuscript received: 31.12.2015

Praca zaakceptowana do druku/Manuscript accepted: 02.01.2017

Tłumaczenie/Translation: Patrycja Groszek 